\title{
Intellectual capital in Malaysian hotel industry: a case study of Malacca
}

\author{
Muhammad Khalique* \\ Department of Business and Management Sciences, \\ Faculty of Arts, \\ Mirpur University of Science and Technology (MUST), \\ Mirpur Azad Jammu and Kashmir, Pakistan \\ Email: drmkhalique@gmail.com \\ *Corresponding author
}

\section{Shazali Abu Mansor}

Department of Economics, Faculty of Economics and Business, Universiti Malaysia Sarawak, 94300-Kota Samarahan, Sarawak, Malaysia Email:mshazali@feb.unimas.my

\begin{abstract}
Intellectual capital is recognised as a crucial strategic asset that provides organisations with a competitive edge and sustainable growth in a cutthroat business environment. There is an increasing comprehension that intellectual capital is critical to organisational performance, this is still an emerging area of inquiry in tourism industry in Malaysia. Therefore, this study was undertaken with the aim to demonstrate the impact of intellectual capital on the organisational performance of hotel industry operating in Malacca, Malaysia. Six components of intellectual capital were used in the study. A total of 193 individuals were involved in this study to test the proposed research hypotheses. The results of multiple regression analysis demonstrated that four out of seven research hypotheses were supported. This study will extend the understanding of the concept and applications of intellectual capital in hotel industry in Malaysia. Moreover, this study will be a milestone for the potential researchers to conduct their further studies in hotel industry.
\end{abstract}

Keywords: intellectual capital; integrated intellectual capital model; IICM; hotel industry; SMEs; Malaysia.

Reference to this paper should be made as follows: Khalique, M. and Mansor, S.A. (2016) 'Intellectual capital in Malaysian hotel industry: a case study of Malacca', Int. J. Business Performance Management, Vol. 17, No. 1, pp.103-116.

Biographical notes: Muhammad Khalique is working as an Assistant Professor in the Department of Business and Management Sciences, Faculty of Arts, Mirpur University of Science and Technology Mirpur (MUST), Pakistan. $\mathrm{He}$ received his $\mathrm{PhD}$ degree from the Universiti Malaysia Sarawak, Malaysia. His teaching and research interests focus on the area of research methodology and report writing, business mathematics, statistics for economics and business, management science, product development strategy and operational management. He has published more than 47 articles in international refereed 